\title{
Epidemiologi Kriptosporidiosis
}

\author{
Esy Maryanti*
}

\begin{abstract}
Cryptosporidiosis is a disease caused by Cryptosporidium sp. Cryptosporidium sp. are single cell of coccidian can infected human and animals. Cryptosporidiosis are considered a cause of emerging and opportunistic infections in human. Oocysts of Cryptosporidium are ovoid or spherical and 4 to 6 micrometers diameters. The parasite is located in the brush border of the epithelial cells of the small intestine. Currently, eight species of Cryptosporidium are known to infect human and there are two species, $C$ parvum and $C$ muris which most common species reported to infect children and immunocompromised patient especially AIDS patient with diarrhea.
\end{abstract}

Key words : Cryptosporidium, AIDS, diarrhea

Cryptosporidium sp. merupakan salah satu parasit usus penyebab diare pada hewan dan manusia. Parasit tersebut sudah ditemukan lebih dari 100 tahun yang lalu. Cryptosporidium sp. pertama kali ditemukan oleh Tyzzer tahun 1907 pada kelenjar lambung mencit yang kemudian diidentifikasi sebagai Cryptosporidium muris. Pada tahun 1912 Tyzzer mengidentifikasi Cryptosporidium spesies lain di usus halus mencit yang kemudian diidentifikasi sebagai C.parvum. Tahun 1976 dilaporkan pertama kali kasus infeksi Cryptosporidium pada manusia yaitu pada seorang anak perempuan yang imunokompeten dan seorang dewasa yang imunosupresi dengan gejala diare. ${ }^{1,2}$

Kriptosporidiosis adalah penyakit yang disebabkan oleh Cryptosporidium sp dan merupakan infeksi oportunistik yang ditemukan baru pada manusia dan hewan. ${ }^{2}$ Dahulu penyakit tersebut merupakan penyakit yang jarang pada manusia. Sebelum tahun 1980 kurang dari 10 kasus yang dilaporkan dan setelah terjadi pandemik AIDS tahun 1985 banyak kasus kriptosporidiosis dilaporkan di berbagai negara antara lain Denmark, Venezuela, Australia, Haiti, Selandia Baru, Muangthai dan Filipina. Pada tahun 1993 di Milwaukee dilaporkan kasus kriptosporidiosis pada 400.000 orang, dan kemudian dinyatakan bahwa Cryptosporidium sp. merupakan patogen oportunistik terutama pada anak-anak dan individu imunokompromis. ${ }^{1,3}$

Saat ini terdapat 16 spesies Cryptosporidium yang telah diidentifikasi tetapi hanya delapan spesies yang diketahui menginfeksi manusia. Di antara delapan spesies tersebut yang utama adalah C.parvum dan C.muris. ${ }^{2}$

Infeksi Cryptosporidium sp. ini dapat menyebabkan diare. Diare yang terjadi dapat merupakan diare akut sampai diare kronis. Pada individu imunokompeten diare dapat sembuh sendiri sedangkan pada individu imunokompromis diare dapat berlanjut menjadi kronis dan bahkan dapat menyebabkan kematian., ${ }^{3,4}$ Di Indonesia kasus kriptosporidiosis belum banyak dilaporkan dan belum menjadi perhatian publik meskipun kasus infeksi Human immunodeficiency virus (HIV) semakin banyak ditemukan. Berdasarkan hal diatas maka pada makalah ini akan dibahas mengenai epidemiologi kriptosporidiosis pada manusia termasuk biologi, siklus hidup, penyakit, distribusi geografis serta sumber infeksi dan cara transmisi.

\footnotetext{
* Penulis untuk korespondensi : Bagian Parasitologi Fakultas Kedokteran, Universitas Riau. Jalan Diponegoro No.1. Pekanbaru 28111

e-mail : esy.maryanti@gmail.com
} 


\section{KARAKTERISTIK BIOLOGI Cryptosporidium sp.}

Cryptosporidium sp. adalah parasit Coccidia bersel tunggal, merupakan protozoa enterosit dengan ukuran sama dengan sel darah merah, yang menginfeksi mukosa usus halus. ${ }^{2}$ Cryptosporidium sp. dikeluarkan dalam tinja pasien yang terinfeksi dalam bentuk ookista. ${ }^{2,3}$ Terdapat 16 spesies Cryptosporidium yang menginfeksi ikan, reptil, burung dan mamalia yaitu C.parvum, C.hominis, C.felis, C.canis, C.wrairi, C.saurophilum, C.suis,
C.scophthalmi, C.bovis, C.andersoni, C.muris, C.serpentis, C.molnari, C.galli, C.meleagridis dan C.baileyi tetapi hanya delapan spesies yang diketahui menginfeksi manusia seperti yang terlihat pada tabel $1 .{ }^{1,2,5}$

Di antara delapan spesies tersebut yang utama dan tersering ditemukan pada manusia adalah C.parvum dan C.muris yang dapat dibedakan berdasarkan ukuran ookista dan sifat patogenisitasnya. Di antara dua spesies tersebut, $C$ parvum lebih patogen dibandingkan C.muris. ${ }^{5}$

Tabel 1. Beberapa spesies Cryptosporidium sp. yang menginfeksi manusia dengan ukuran ookista, tempat infeksi dan hospes utama ${ }^{5}$

\begin{tabular}{|c|c|c|c|}
\hline Spesies & Ukuran ookista (um) & Tempat infeksi & Hospes utama \\
\hline Chominis & $4,5 \times 5,5$ & Usus halus & Manusia \\
\hline C. parrim & $4,5 \times 5,5$ & Usus halus & $\begin{array}{l}\text { Mamalia neonatus, } \\
\text { manusia }\end{array}$ \\
\hline C. suis & $5,05 \times 4,41$ & Usus halus & Babi \\
\hline C. felis & $4,5 \times 5,0$ & Usus halus & Kucing \\
\hline C. canis & $4,95 \times 4,71$ & Usus halus & Anjing \\
\hline C. meleagricts & $4,5-4,0 \times 4,6-5,2$ & Usus & Kalkun \\
\hline C. muris & $5,5 \times 7,4$ & Perut & Tikus \\
\hline C. andersoni & $5,6 \times 7,4$ & Petut & Sapi, Unta \\
\hline
\end{tabular}

Bentuk infektif dari Cryptosporidium sp. adalah ookista yang dikeluarkan dalam tinja hospes yang terinfeksi. Ookista yang terbentuk ada dua macam yaitu ookista berdinding tipis dan tebal. Ookista berdinding tipis mengeluarkan sporozoit di dalam usus dan menyebabkan autoinfeksi, sedangkan yang berdinding tebal dikeluarkan bersama dengan tinja. Ookista matang berisi empat sporozoit yang akan menempel dan memasuki enterosit. ${ }^{3,6}$ Sporozoit yang berbentuk pisang dikeluarkan melalui dinding ookista yang terbuka oleh pajanan suhu tubuh, asam, tripsin dan garam empedu. Sporozoit memiliki sebuah kepala yang kecil. Sporozoit mengandung granul, mikronema, nukleus, nukleolus, komplek golgi, membran unit ganda dan retikulum endoplasma. Mikrotubul yang berperan penting untuk pergerakan keluar dan invasi, terletak di bawah membran plasma. Nukleus berada di bagian mid-terminal posterior. Mitokondria dapat dilihat sejajar dengan nukleus sperti terlihat pada gambar 1. ${ }^{5}$ Setiap nukleus dari sporozoit mengandung delapan kromosom yang terdiri atas 10,1-10,4 miliar pasang basa DNA. ${ }^{7}$
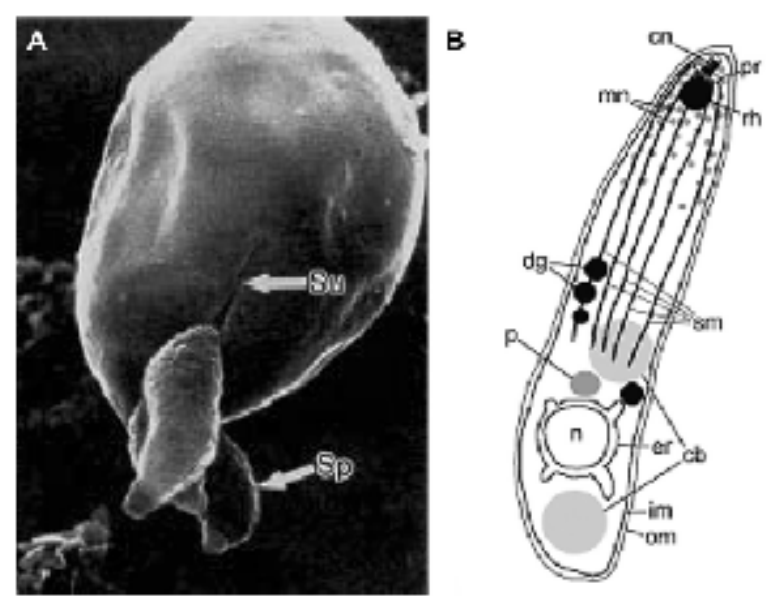

Gambar 1. Ekskistasi sporozoit dari ookista C.parvum ${ }^{7}$

\section{HABITAT DAN SIKLUS HIDUP Cryptosporidium sp. PADA MANUSIA}

Cryptosporidium sp. pada manusia tidak hanya di usus halus, tetapi juga di organ-organ lain seperti faring, esofagus, lambung, duodenum, yeyunum, ileum, appendiks, kolon, rektum, kandung empedu dan saluran pankreas. Infeksi terberat ditemukan di 
yeyunum. Pada individu immunokompeten, parasit biasanya terbatas di usus halus sedangkan pada individu imunokompromis dapat ditemukan sepanjang saluran pencernaan, selain itu juga dapat ditemukan pada sistem hepatobiliary dan saluran pernafasan., ${ }^{2,6}$

Cryptosporidium sp. di dalam usus, melekatkan diri di permukaan sel epitel pada "brush border". Perkembangan parasit terjadi di dalam vakuola parasitoforus. Parasit ini intraseluler, tetapi ekstrasitoplasmik pada brush border sel hospes. ${ }^{2}$ Pada pangkal perlekatan antara parasit dan mikrovili ada daerah yang mengalami fusi. Daerah tersebut mempunyai struktur sangat tipis dan berbentuk lipatan-lipatan yang disebut feder organella yaitu tempat terjadinya aliran nutrisi dari sel hospes ke parasit Cryptosporidium sp. ${ }^{2,8}$

Infeksi Cryptosporidium sp. terjadi bila tertelan ookista matang yang dikeluarkan oleh tinja hospes terinfeksi. Masa prepaten yaitu waktu antara infeksi dan pengeluaran ookista selama $4-22$ hari untuk manusia dan dapat lebih dari 30 hari pada individu imunokompeten. ${ }^{6}$ Siklus hidup Cryptosporidium sp. terdiri dari enam tahap perkembangan. Siklus seksual dan aseksual berlangsung dalam satu tubuh hospes (monoxenous) di saluran pencernaan. ${ }^{1,3}$ Siklus hidupnya dimulai dengan ekskistasi yang terjadi di traktus gastrointestinal atas. Sporozoit keluar dari ookista dan menempel pada sel epitel usus yang kemudian menjadi trofozoit. Trofozoit dan stadium-stadium selanjutnya hanya terdapat pada permukaan sel epitel, tidak masuk ke dalam sitoplasma epitel tersebut. Trofozoit mengalami skizogoni dengan tiga kali pembelahan inti dan terbentuk skizon generasi pertama yang mengandung delapan merozoit. Skizon pecah dan keluar delapan merozoit yang dapat menginfeksi sel epitel lain. Merozoit generasi pertama mengalami skizogoni lagi dengan dua kali pembelahan inti sehingga terbentuk skizon generasi kedua yang mengandung empat merozoit. Skizon tersebut pecah dan keluar merozoit yang dapat menginfeksi sel epitel lain, selain itu merozoit tersebut ada yang tumbuh menjadi makrogametosit dan mikrogametosit. Makrogametosit mengalami perkembangan dan berubah menjadi makrogamet. Satu makrogametosit akan berubah menjadi satu makrogamet. Mikrogametosit mengalami pembelahan inti beberapa kali dan berubah menjadi beberapa mikrogamet ( 12-16 mikrogamet ). Satu mikrogamet akan membuahi satu makrogamet sehingga terbentuk zigot. Zigot akan berkembang menjadi ookista yang mengandung empat sporozoit. ${ }^{1,3}$ Siklus hidup Cryptosporidium sp. ini dapat dilihat pada gambar 2 .

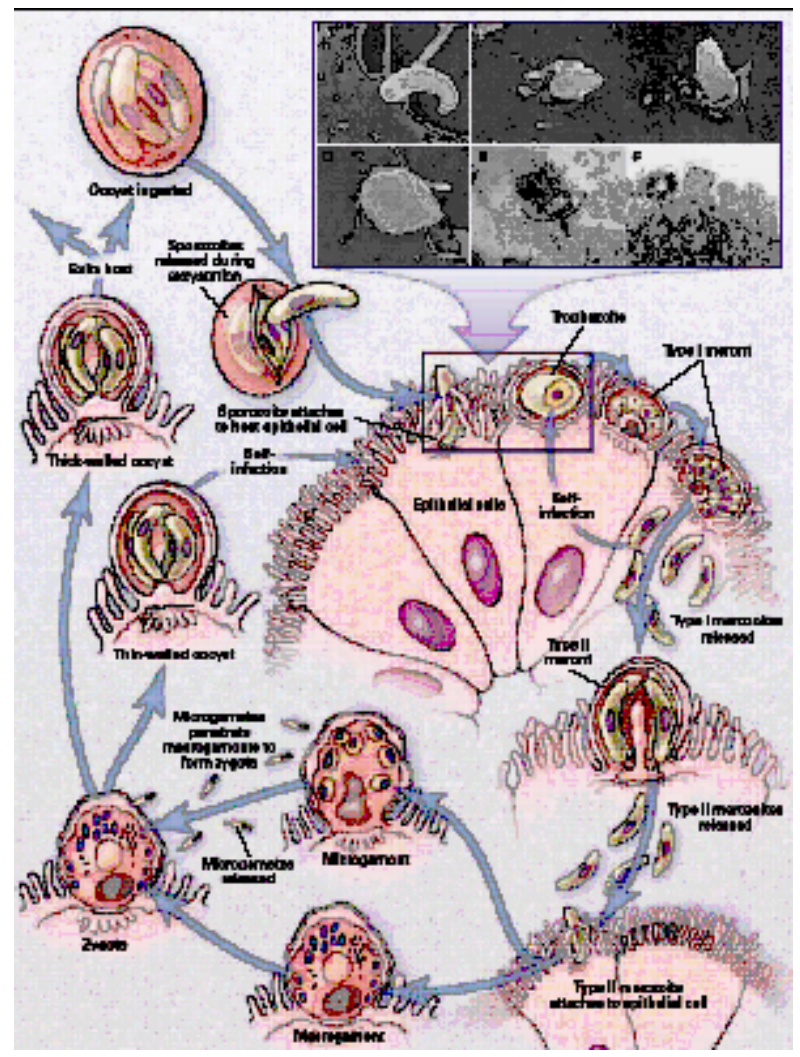

Gambar 2. Siklus hidup Cryptosporidium sp. ${ }^{9}$

\section{MANIFESTASI KLINIS KRIPTOS PORIDIOSIS}

Manifestasi klinis kriptosporidiosis tergantung pada status imun penderita. Pada individu imunokompeten infeksi Cryptosporidium sp. dapat bersifat asimptomatik atau dengan gejala diare akut yang dapat sembuh sendiri. Pada individu imunokompromais seperti pada pasien HIV/ Acquired immunodeficiency syndrome (AIDS) manifestasi klinis mulai dari infeksi tanpa gejala, diare akut sampai dengan diare kronis. Diare dapat berlangsung selama empat bulan dan pernah dilaporkan sampai tiga tahun. ${ }^{8}, 10$ Patofisiologi diare pada kriptosporidiosis tidak spesifik, diduga sama dengan toksin kolera. Diare yang terjadi tidak disertai darah, cair dan tidak selalu profuse. Jumlah cairan yang hilang melalui tinja sekitar 3 - 17 liter/ hari.. ${ }^{11}$ 
Manifestasi klinis kriptosporidiosis selain diare adalah demam ringan, pusing, nyeri ulu hati, mual, muntah, anoreksia, sukar tidur yang akan berakibat pada penurunan berat badan. Kematian tidak langsung disebabkan oleh Cryptosporidium sp., tetapi diare dan malnutrisi merupakan faktor penting. ${ }^{12}$ Kriptosporidiosis juga dapat terjadi pada individu dengan status immunokompromais yang lain, seperti agammaglobulinemia kongenital, defisiensi IgA, dan kanker. ${ }^{4,13}$

\section{DISTRIBUSI GEOGRAFIS DAN PREVALENSI KRIPTOSPORIDIOSIS PADA MANUSIA}

Kriptosporidiosis pada manusia mempunyai distribusi yang luas di seluruh dunia. Infeksi Cryptosporidium sp. ini dapat terjadi pada semua tingkatan usia mulai dari bayi berusia tiga hari sampai individu yang berumur 95 tahun tergantung pada status imun penderita. Kriptosporidiosis rentan terjadi pada anak-anak usia 1-5 tahun, wanita hamil dan individu immunokompromis. Pada penelitian dilaporkan bahwa laki-laki cenderung lebih banyak terinfeksi daripada perempuan. ${ }^{2,13,14}$

Tahun 1997 di Amerika Serikat dilaporkan kasus kriptosporidiosis pada penderita AIDS dengan diare sebanyak $10-20 \% .{ }^{15}$ Pada penderita HIV positif di Eropa dan Los Angeles ditemukan sebanyak 6,6\% dan 3,8\% kasus kriptosporidiosis. Lebih dari 50\% infeksi Cryptosporidium sp. pada penderita AIDS dilaporkan di Afrika dan Haiti. ${ }^{15}$

Prevalensi kriptosporidiosis di Brazil selama 10 tahun (1990-2000) ditemukan 1,1\%-17,4\%. ${ }^{14}$ Infeksi Cryptosporidium sp. pada tahun $1997 \mathrm{di}$ Bolivia mencapai 32\%. ${ }^{6}$ Sebanyak $63 \%$ anak positif Cryptosporidium sp. di Perusia pada tahun 1997, infeksi tersebut tanpa gejala. ${ }^{2}$ Kasus kriptosporidiosis positif ditemukan sebanyak 6 dari $522(1,1 \%)$ pada laki-laki dan 3 dari $420(0,7 \%)$ pada perempuan non HIV di Korea pada tahun 2005. ${ }^{16}$

Cryptosporidium sp. di Indonesia sudah mulai dilaporkan pada tahun 1989, yaitu ditemukannya 4 dari 413 anak positif ookista Cryptosporidium sp. dengan gejala diare. ${ }^{17}$ Sebanyak 1,3\% (11 dari 838) anak dengan diare dan $0,65 \%$ (4 dari 617) penderita dewasa yang dirawat di beberapa rumah sakit di Jakarta positif dengan Cryptosporidium sp. pada tahun 1990. ${ }^{18}$ Prevalensi Cryptosporidium sp. di Surabaya pada tahun 1992-1993 sebanyak 2,8\% pada anak diare dan 1,4\% pada anak tidak diare. ${ }^{19}$ Tahun 2007 Kurniawan A, dkk melaporkan sebanyak 34\% tinja anak batita (bawah tiga tahun) di Jakarta positif dengan Cryptosporidium sp. ${ }^{20}$

Ada beberapa cara transmisi Crytosporidium yaitu;

\section{- Transmisi dari manusia ke manusia}

Transmisi ini merupakan bentuk utama transmisi Cryptosporidium sp. Infeksi dapat terjadi secara fekal oral dan kontak langsung dengan penderita . Anak dan pekerja di tempat penitipan anak serta wisatawan berisiko tinggi terhadap infeksi Cryptosporidium sp. ${ }^{4}$

\section{- Transmisi dari hewan ke manusia}

Cryptosporidium yang menginfeksi hewan juga dapat menginfeksi manusia atau sebaliknya, seperti anak babi, kucing, anjing dan tifus dapat menjadi hospes reservoar parasit ini. ${ }^{4,10}$ Manusia dan hewan mempunyai peluang yang sama sebagai sumber penularan Cryptosporidium. Lebih dari 150 spesies mamalia yang telah dilaporkan dapat menginfeksi manusia. ${ }^{21}$

\section{- Transmisi melalui air minum}

Ookista Cryptosporidium sp. terdistribusi luas di lingkungan perairan, kolam renang dan taman air untuk bermain anak-anak dapat menjadi sumber penularan Cryptosporidium. Ookista Cryptosporidium sp. dapat ditransmisikan melalui air minum yang diberi klor karena klorinasi air minum tidak dapat membunuh ookista Cryptosporidium sp. $^{21,22}$

\section{PENUTUP}

Kriptosporidiosis merupakan penyakit yang disebabkan oleh Cryptosporidium sp. yang dapat mengenai hewan dan manusia. Penyakit ini sering terjadi pada anak dan penderita imunokompromais dengan gejala diare. Penderita dengan defisiensi imun yang berat dan malnutrisi sangat rentan terhadap infeksi Cryptosporidium sp. dan bila tidak diobati dapat menyebabkan kematian. Penyebaran 
Cryptosporidium sp. yang luas di seluruh dunia dan cara transmisi yang mudah, menyebabkan penyakit ini semakin hari prevalensinya semakin meningkat.

\section{DAFTAR PUSTAKA}

1. Fayer R, Ungar BL. Cryptosporidium sp. and cryptosporidiosis. Microbiol Rev. 1986;50(4):458-83.

2. Clark DP. New insights into human cryptosporidiosis. Clin Microbiol Rev. 1999;12(4):554-63.

3. Current WL, Garcia LS. Cryptosporidiosis. Clin Microbiol Rev. 1991;4(3):325-58.

4. Roy SL, DeLong SM, Stenzel SA. Risk factor for sporadic cryptosporidiosis among immunocompetent persons in the united states from 1999 to 2001. J Clin Microbiol 2004; 42(7):2944-51.

5. Smith HV, Nichols RAB. Cryptosporidium (Chapter 9) dalam Foodborne Diseases. Shabbir Simjee editor. Totowa, New Jersey: Humana Press, 2007. p.233-76.

6. Sears CL, Kirkpatrick BD. Cryptosporidiosis and isosporiasis. In: Gillespie SH, Pearson RD, editors. Principles and practice of clinical parasitology. New York: John Wiley \& Sons, Inc., 2001; p.139-59.

7. Xiao L, Fayer R, Ryan U, Upton SJ. Cryptosporidium taxonomy: recent advances and implications for public health. Clin Microbiol Rev. 2004;17(1):72-97.

8. Kourtis AP. Cryptosporidiosis. E medicine. 2006. Diakses tanggal 3 Maret 2010.

Available from: http://www.emedicine.com/ ped/topic516.htm.

9. Chen, Xian-Ming, Keithly JS, Paya CV, LaRusso NF. Current concepts: cryptosporidiosis. The New England Journal of Medicine. 2002; 346(22)

10.Palmateer G. Cryptosporidium parvum is a very successful and lethal parasite. Environmental Science and Engineering. 2003. Diakses tanggal 3 Maret 2010. Available from: http:// www.esemag.com/index.html.
11. Southwick FS. Infectious Diseases in 30 Days. New York: McGraw-Hill Companies, Inc. Medical Publishing Division; 2003

12.Khan WA, Rogers KA, Karim MM, Ahmed S, Hibberd PL, Calderwood SB, et al. Cryptosporidiosis among Bangladeshi children with diarrhea: a prospective, matched, casecontrol study of clinical features, epidemiology and systemic antibody responses. Am J Trop Med Hyg. 2004;71(4):412-419.

13.Hunter PR, Nichols G. Epidemiology and clinical features of Cryptosporidium infection in immunocompromised patients. Clin Microbiol Rev. 2002;15(1):145-54.

14.Pereira MDGC, Atwill ER, Barbosa AP, Silva SAE, Zapata MTAG. Intra-familial and extrafamilial risk factors associated with Cryptosporidium parvum infection among children hospitalized for diarrhea in Goiania, Goias, Brazil. Am J Trop Med Hyg. 2002;66(6):787-93.

15.Goodgame RW. Understanding intestinal sporeforming protozoa: Cryptosporidia, Microsporidia, Isospora, and Cyclospora. Annals of Internal Med [serial online]. 1996;124(4):42941. Diakses tanggal 3 Maret 2010. Available from: http://www.annals.org/cgi/content/full/ $\underline{124 / 4 / 429}$.

16.Lee JK, Song HJ, Yu JR. Prevalence of diarrhea caused by Cryptosporidium parvum in non-HIV patients in Jeollanam-do, Korea. The Korean $\mathbf{J}$ of Parasitol. 2005;43(3):111-4.

17.Rasad R, Adjung SA, Rukmono B, Sunoto, Suharyono. Cryptosporidium infection in children with diarrhea. 25 th Annual Scientific Seminar, Research priorities for Trop Med in the 90's. (Makalah ini telah dikemukakan dalam: " $25^{\text {th }}$ Silver Jubilee Seminar of the Malaysian Society of Parasitology and Tropical Medicine 23 rd - 25 th February 1989”).

18. Katsumata T, Hosea D, Wasito EB, Kohno S, Hara K, Soeparto P, et al. Cryptosporidiosis in Indonesia: a hospital-based study and a community-based survey. Am J Trop Med Hyg. 1998;59:628-32.

19. Ghani, Lannywati. Faktor -faktor risiko diare 
persisten pada anak balita. Badan Litbangkes Depkes RI. J Kedokter Trisakti. 2001.

20.Kurniawan A, Dwintasari SW, Soetomenggolo HA, Wanandi SI. Detection of Cryptosporidium sp infections by PCR and modified acid fast staining from potassium dichromate preserved stool. Medical Journal of Indonesia. 2009;18(3):149-55.
21.Smith HV. Diagnosis of human and livestock cryptosporidiosis (Chapter 6) dalam Cryptosporidium and cryptosporidiosis. Fayer R, Xiao L editor. $2^{\text {nde }}$ d.London: $\quad$ CRC press;2007.p.173-203.

22.Smith HV. Environmental aspects of Cryptosporidium species: a review. J Royal Society of Med. 1990;83:629-31. 